\title{
Legal Protection Of Welfare Teacher Assistant Garden Children
}

\author{
Kusti'ah ${ }^{1}$
}

\begin{abstract}
The problems that arise in this research are: 1 . What is the Realization of Legal Protection for Kindergarten Assistance Teachers' Welfare in Demak Regency, 2. What Barriers Arise in Protecting the Rights of Kindergarten Assistance Teachers in Demak Regency, 3 How is the Kindergarten Assistance Teacher Contract Completion after the employment contract ends.

The method used in this research is qualitative descriptive with the research location in Demak Regency. Data sources use primary and secondary data. Respondents in this study were drawn by means of "purposive sampling". Data collection techniques by interview, observation and documentation. Data analysis uses inductive thinking with a flow analysis model which is divided into three main components. To determine the final result, an interactive analysis model is used.

The results of the discussion and analysis of this study indicate that the Decree of the Minister of Education No. 034 / U / 2003 Regarding Assisted Teachers, it does not explicitly provide legal protection for the welfare of Kindergarten Assistance Teachers. Barriers that arise in protecting the rights of Assistance Teachers are the absence of the relevance of regulations applicable to Kindergarten Assistance Teachers. The completion of the Assistance Teacher contract agreement after the work contract ends, a Contract Agreement (SPK) is signed once a year until the age of 60 years, if evaluated it still meets the formal requirements. The implementation of legal protection for the welfare of Kindergarten Assistance Teachers has not been as expected. Keywords: Legal Protection, Assistance Teacher Welfare,
\end{abstract}

\section{Introduction}

Expectations can meet the needs of teachers which increase every year along with the addition of students / students proportionally and professionally. This is understandable because the existing teachers actually do not meet the needs of the education world for teachers, while it is known that the problem of teacher shortages is one of the obstacles that has a negative impact on education development efforts. Some of the teachers currently in schools are still nonpermanent teachers with relatively low salaries and their numbers are still relatively inadequate to meet the needs of teachers in schools because they are related to the financial capacity of schools for procurement.

Although it is well aware that with the enactment of Law no. 22 of 1999 Jo No. 32 of 2003 concerning Regional Government has provided opportunities for autonomous regions, namely Provincial, Regency / City levels to receive authority in efforts to develop regional potential and capabilities which include education and culture, so the addition and procurement of teachers is the responsibility of the

\footnotetext{
${ }^{1}$ Government employees, Head of Kindergarten
} 
regions. Considering that the regional capacity to provide funding for teacher procurement is felt to be insufficient, it is the responsibility of the central government to fulfill the need for teachers, in this case the Ministry of National Education. Dr. Ir. Indra Djati Sidi stated, given the limited education budget available to appoint civil servants as teachers, ${ }^{2}$

Therefore, in the context of implementing Assisted Teacher recruitment, as a continuation of the provision of Assisted Teachers in 2003, the central government through the Ministry of National Education, the Directorate General of Primary and Secondary Education carried out the procurement of Assisted Teachers in 2004. The implementation of Assisted Teacher Program in 2004 was held by considering, among others, :Considering that the provision of Assisted Teachers in 2003 has not fully met the needs of the shortage of teachers, especially in remote areas; Input from the regions, especially from the District / City Education Office regarding the benefits of implementing Assistance Teachers in 2003 in supporting a conducive teaching and learning process.

\section{Research methods}

The approach method used is juridical sosilogical, the specification in the research is descriptive analytical, population and sampling methods are all objects or all symptoms or all events or all units to be studied, data collection techniques use literature study and interviews, data analysis used is qualitative. Data were obtained or collected from interviews with DINDIKPORA in Demak Regency and several school principals in each Sub-district in Demak Regency who used Assistance Teachers.

\section{Research Results And Discussion}

Education is very much needed by every resident, even every resident has the right to be able to get education, especially elementary school age (7-12 years).

The success of education is greatly influenced by the availability of educational facilities and infrastructure such as schools and adequate education personnel (teachers).

The implementation of social welfare includes individual welfare and community welfare which consists of 1 . increasing spiritual values for individuals and society, 2. meeting the needs of life, which includes 6 things, among others: a. training and education according to their talents, b. Availability of jobs in accordance with talents, abilities and skills as well as community needs c. enough to eat and drink d. comfortable house e. environmental health in general and combined with suitable health facilities, and f. fulfillment of place facilities that make it easier for workers to work. ${ }^{3}$ So that Kindergarten Assistance Teachers in Demak Regency can get legal protection for welfare regarding work wages, occupational health, work

\footnotetext{
2 Indra Djati Sidi, 2004, Pedoman Pelaksanaan Program Guru Bantu, Departemen, Pendidikan Nasional, Ministry, National Education, Jakarta, p. 6

${ }^{3}$ M. Umar Chapra, 1981, The Islamic Welfare State and its Role in The Economjy. In Mursid Ahmad Studies in Islamic Economics, The Islamic Foundation, United Kingdom. p. 145
} 
accidents, get health insurance and get old age insurance in the form of severance pay as an award while serving the government.

The society desires a harmonious religious life. The variety of places of worship is one proof of religious harmony among the people. The number of places of worship in Demak Regency in 2010 reached 4,493, in the form of 4,463 mosques / musholla, 26 churches, and 1 temple.

In the development of the religious sector, Demak Regency is also supported by the existence of 180 Islamic boarding schools with a registered number of students as many as 34,100 people.

Judging from the number religion The majority of the population in Demak Regency is Muslim, reaching 98.82 percent of the total population, the rest is divided into Christian, Catholic, Hindu and Buddhist residents.

\subsection{Auxiliary Teacher Management Organizational Structure}

\subsubsection{Rights and Obligations of Assisting Teachers}

Assisted Teachers are entitled to receive honoraria provided by the Government through the State Budget and distributed by the Regional Government budgets through the District Government at Bank Central Java, so that the auxiliary Teachers concerned can take their honorariums to the Bank Jateng account at least the 4 th of each month.

Auxiliary teachers have the right to legal protection, namely protection of work wages that can fulfill the needs of their family life and also work safety.

Auxiliary Teachers have an obligation a. carrying out teaching duties, training, guiding students according to applicable regulations, b. carry out administrative tasks in accordance with applicable regulations, c. comply with all provisions in the school where assignment is, and $\mathrm{d}$. comply with the provisions stipulated in the Work Agreement (SPK).

\subsubsection{Assisted Teacher Work Agreement}

Auxiliary Teachers are teachers who are not Civil Servants who have the position of Employees of the Ministry of National Education who are fully assigned to schools. In this case the Kindergarten Assistance Teacher is assigned to TK Pertiwi Bango, Demak Regency. The work agreement is binding between the parties, so that if someone is already bound in an agreement, it cannot be canceled, unless both parties agree to revoke it.

Based on Article 1 in the Work Agreement Letter (SPK), the agreement between the Head of the Youth and Sports Education Office of Demak Regency and the teacher concerned that the Regent / Head of the Youth and Sports Education Office assigns jobs to assisting Kindergarten Teachers with duties as classroom teachers in Kindergarten -Children of Pertiwi Bango, Demak Regency. As a classroom teacher, Kindergarten Assistance Teachers are tasked with planning, carrying out teaching and learning activities, evaluating evaluating and guiding counseling of students.

Based on Article 2 in the Work Agreement, Kindergarten Assistance Teachers are obliged to: a. carry out teaching duties, training, guiding students on duty $b$. carry out educational administrative tasks c. comply with the applicable provisions 
in Kindergarten $\mathrm{d}$. provide reports on the implementation of assignments in each semester and at the end of the school year to the Principal.

This shows that both parties have agreed to do everything that arises and results from this agreement, so that both parties cannot deny each other what is written in the agreement.

Then in article 2 paragraph (2) states that: a. Auxiliary Teachers have the right to be appointed as Assisting Teachers in Kindergarten, b. Kindergarten Assistance Teachers are entitled to an honorarium of Rp. 710,000 (seven hundred and ten thousand rupiah) per month and a Central Java Bank account with a minimum limit of the 4th day of the month can be received by the teacher concerned, c. Auxiliary teachers are entitled to leave based on the regulations of the labor law, including one month before giving birth and two months after giving birth, $d$. Assistive teachers have the right to legal protection in carrying out their duties regarding work wages, work safety, work accidents with health insurance.

Article 4 in the Work Agreement Letter states that a. Kindergarten Assistance Teachers who have ended their employment agreement can be extended as needed and the results of the assisted teacher performance evaluation during their assignment by the Principal are known to the local UPTD Dikpora Head, b. Every extension or making a Work Agreement is carried out at least 1 year of extension based on the evaluation of the School Principal known to the Head of the UPTD Dikpora Kecamatan, c. The work agreement period can be extended to a maximum age of 60 years by means of a 1 year agreement with the Head of the District Youth and Sports Education Office based on the monitoring and evaluation of the principal and the Head of the UPTD Dikpora Kecamatan.

Based on the Articles above, it is clear that juridically it is very contradictory to Law No. 13 of 2003 concerning Manpower, whereas according to Article 1 of Law no. 13 of 2003, workers are company employees and not assisting teachers. Supposedly assisting teachers are under the auspices of the Ministry of National Education, and besides that the rules also adhere to Law No. 20 of 2003 concerning the National Education System, but in Law no. 20 of 2003 concerning the National Education System does not regulate contract agreements for assisting teachers, how are their welfare, wages, old age security, and others.

This problem is possible because the human resources of the Assisted Teachers are not proportional to the total need for Assisted Teachers. Human resources and labor force growth are still relatively high. The availability of the quality of the highly educated workforce tends to increase. In an unequal labor market conditions, there will be intense competition from the workforce to fight for limited job opportunities. This condition causes the weak position of workers in the work relationship. Even so, Assisting Teachers still have the right to legal protection in carrying out their duties, because they are bound by work agreements / contracts whose arrangements do not exist in Law No. 20 of 2003 concerning the National Education System and in Law no. 13 of 2003 concerning Manpower.

\subsection{Distribution of Assistance Teacher Fund}

The Honorarium for Assisting Teachers comes from the Ministry of National Education of the Republic of Indonesia, then received by the Central Java Provincial 
Government, then through the District Government (Youth and Sports Education Office of Demak Regency) it is transferred through the Central Java Bank, Demak Regency Branch to the respective Assisting Teachers who are at least the 4th of every the month has entered the account.

The realization of legal protection for the welfare of Kindergarten Assistance Teachers in Demak Regency has basically experienced an increase, especially in relation to honoraria. However, every year there is still a Work Contract Agreement (SPK) between Kindergarten Assistance Teachers and the Head of the Youth and Sports Education Office in Demak Regency.

Obstacles That Arise in Protecting the Rights of Kindergarten Assistance Teachers are Assisted Teachers as contract workers when viewed from the Manpower Act, but in Law No. 20 of 2003 concerning the National Education System Teachers are professional or functional personnel. This is due to the implementation of the Decree of the Minister of National Education No. 034 / U / 2003 Concerning Assisted Teachers is contrary to Law No. 13 of 2003 concerning Manpower.

Completion of the Assistance Teacher Work Contract Agreement after the work contract ends, a Work Agreement (SPK) is signed between Kindergarten Assistance Teachers and the Head of the Demak District Youth and Sports Education Office every once a year until the age of 60 years if evaluated still meets formal requirements based on recommendations from the Head of Kindergarten, it is known that the Head of the Technical Implementation Unit of the Subdistrict Youth and Sports Education Office

\section{Closing}

\subsection{Conclusion}

From the discussion above, the researcher can conclude this research is as follows: The realization of legal protection for the welfare of Kindergarten Assistance Teachers in Demak Regency has basically increased, particularly in relation to honoraria. However, every year there is still a Work Contract Agreement (SPK) between Kindergarten Assistance Teachers and the Head of the Youth and Sports Education Office of Demak Regency. The impact that can be seen is the absence of work safety benefits, occupational health, work accidents, retirement benefits, and old age insurance protection. This is because the Assistance Teacher is a contractual status, which acts as a casual daily worker who only receives what is in the agreement in the form of an honorarium without other rights; Obstacles That Arise in Protecting the Rights of Kindergarten Assistance Teachers are Assisted Teachers as contract workers when viewed from the Manpower Act, but in Law No. 20 of 2003 concerning the National Education System Teachers are professional or functional personnel. This is due to the implementation of the Decree of the Minister of National Education No. 034 / U / 2003 Concerning Assisted Teachers is contrary to Law No. 13 of 2003 concerning Manpower; Completion of the Assistance Teacher Work Contract Agreement after the work contract ends, a Work Agreement (SPK) is signed between Kindergarten Assistance Teachers and the Head of the Demak District Youth and Sports 
Education Office every once a year until the age of 60 years if evaluated still meets formal requirements based on recommendations from the Head of Kindergarten, it is known that the Head of the Technical Implementation Unit of the Subdistrict Youth and Sports Education Office

\subsection{Suggestions}

a. Work Agreement (SPK) so that it is implemented once every year with a recommendation letter from the School Principal known to the Head of the Technical Implementation Unit of the District Youth and Sports Education Office

b. Regarding welfare, it is regulated based on Regional Regulation at least UMR in Demak Regency

c. It needs to be regulated in a Regional Regulation a minimum working period of 10 years for assisting teachers without disabilities / as long as the formal requirements are met can be submitted as a Civil Servant.

d. If there is no formation, there should be an arrangement for old age allowances for Assisting Teachers

e. If the Batu Teacher can be appointed as a Civil Servant, the working period is calculated as the previous service period or is recognized as $80 \%$

\section{Bibliography}

Indra Djati Sidi, 2004, Pedoman Pelaksanaan Program Guru Bantu, Departemen, Pendidikan Nasional,, Ministry, National Education, Jakarta,

M. Umar Chapra, 1981, The Islamic Welfare State and its Role in The Economjy. In Mursid Ahmad Studies in Islamic Economics, The Islamic Foundation, United Kingdom

Moleong, Lexy J., 2001, Metodologi Penelitian Kualitatif, PT Remaja Rosdakarya, Bandung.

Musbikin, Imam, 2010, Guru Yang Menakjubkan!, Buku Biru, Yogyakarta.

Robinson, W. and J. Campbell, 2010, “Evaluation of Teacher Quality and 